\title{
Diet and inequalities in health in three English towns
}

\author{
J E CADE, D J P BARKER, B M MARGETTS, J A MORRIS
}

\begin{abstract}
The diets of 2340 middle aged men and women living in three English towns were recorded. Consumption of fat and the other main nutrients was lowest in the northern industrial town, which had the highest death rates from ischaemic heart disease and from all causes combined.

The findings suggest that differences in diet in middle age are not a major cause of differences in adult mortality between one part of Britain and another.
\end{abstract}

\section{Introduction}

Differences in the diets of middle aged men and women are thought to contribute to the large geographical and social class differences in mortality and morbidity in Britain. Evidence, however, is lacking. The National Food Survey, which each year records food purchases within a sample of around 7500 households, is the only large source of data on the national diet, but it does not record consumption separately for men and women or at different ages. ${ }^{1}$

We describe the first large study comparing the diets of middle aged men and women in different areas of England with differing mortality and morbidity from diseases thought to have dietary causes.

\section{Population and methods}

The three towns studied, Ipswich, Stoke-on-Trent, and Wakefield, were included among nine towns in England and Wales previously selected for a series of morbidity surveys. ${ }^{2}$ The towns were defined by the local authority boundaries used before the changes in 1974. Socioeconomic indices were abstracted from published data from the 1981 census. $^{3}$ The Office of Population Censuses and Surveys made available to us extracts from all death certificates in England and Wales during 1968-78, the period covered by the eighth revision of the International Classification of Diseases (ICD). Death rates for each sex for each town were calculated from 1971 census data. ${ }^{4}$ Death rates were expressed as standardised mortality ratios.

In each town a sample of men and women aged 35-54 was taken from the lists of general practitioners. To obtain a social class distribution representative of the town the practices were in different electoral wards. In Ipswich there were 14 practices from 10 of the 16 wards, in Stoke 16 practices from 16 of the 20 wards, and in Wakefield five practices from three of the four wards. People were selected by stratified random sampling to give equal numbers in each five year age group in each sex.

We recorded diet by using a 24 hour diary. In comparing the diets of populations it is statistically efficient to have only one day of recordings on each subject and to maximise the number of subjects rather than have two or more days of observations on fewer subjects. ${ }^{5}$ Using data from previous dietary studies in Britain $^{6.8}$ we estimated that completion of a 24 hour dietary record by samples of 400 men and 400 women in each town would give a $90 \%$ chance of detecting differences between any two towns of $10 \%$ or more (at the $5 \%$ level of significance) in mean daily intakes of energy, total fat, carbohydrate, protein, and total dietary fibre. To achieve this sample size 1150 people were selected initially after a pilot study in Stoke had suggested

MRC Environmental Epidemiology Unit, University of Southampton, Southampton General Hospital, Southampton SO9 4XY

J E CADE, PHD, nutritionist

D J P BARKER, PHD, FRCP, director

B M MARGETTS, PHD, nutritionist

J A MORRIS, MSC, statistician

Correspondence to: Dr Cade. that $30 \%$ of those approached would be unavailable for the survey-usually because they had moved from the address on the general practitioner's list. In each town the survey was carried out during 16 weeks evenly spread through the year May 1984 to April 1985.

An introductory letter signed by the general practitioner was sent to each subject. He or she was asked to complete a 24 hour dietary diary on a specified day during the following week. Days for diary keeping were allocated to give equal numbers for each day of the week. Subjects recorded quantities of food in terms of household measures. A pilot study of 33 people showed that, except for total dietary fibre and vitamin A, estimates of intake of the main nutrients based on household measures were within $10 \%$ of those based on weighed food records.

Before the survey a local interviewer was appointed in each town and trained. As soon as possible after the diary day, usually the next day, the local interviewer or one of us (JC) visited the subject at home. The diaries were checked, sizes of portions clarified by using standard models, and the volumes of household utensils measured. If the subject had not kept the diary either another day was allocated or a 24 hour recall for the previous day was taken at interview. Data on fatty foods and vitamins A and C were extended by means of a food frequency questionnaire.

The subjects were also asked about smoking, alcohol consumption, occupation, and residential history. Questions on alcohol were based on those used in the British regional heart study. ${ }^{9}$ At interview subjects were weighed on a portable Seca scale and height measured by a stadiometer.

Nutrient intakes were derived from food consumption by using computerised food composition tables. ${ }^{10-12}$ When intakes were not normally distributed by reference to the Kolmogorov-Smirnov goodness of fit test they were transformed by using a square root or natural logarithm value. Generalised linear interactive modelling was used for regression analyses. ${ }^{13}$

\section{Results}

Table I shows socioeconomic indices in the towns. The indices describe social class distribution, housing, and income, the last as indicated by the proportion of households owning their house or a car. In Ipswich, a southern market town with agricultural industries, the indices were generally around or better than the average for England and Wales. In Stoke, a Midlands town and centre for the pottery industry, and in Wakefield, a northern wool and coal mining town, socioeconomic conditions were generally below average. Stoke has a high proportion of people in manual occupations.

Table II shows the death rates and morbidity. All cause standardised mortality ratios at ages 35-74 were lowest in Ipswich (92 in men, 90 in women). Among men they were similarly high in Stoke and Wakefield (120, 118 ), whereas among women those in Wakefield were higher (131) than in Stoke (117). The pattern of ischaemic heart disease was similar, rising in both sexes combined from 86 in Ipswich to 119 in Stoke and 123 in Wakefield. Trends in mortality from breast cancer, incidence of colonic

TABLE I-Socioeconomic indices in the three towns in 1981

\begin{tabular}{|c|c|c|c|c|}
\hline & Ipswich & Stoke & Wakefield & $\begin{array}{l}\text { England and } \\
\text { Wales }\end{array}$ \\
\hline \multicolumn{5}{|l|}{$\%$ Of people in social classes ${ }^{\star}$ : } \\
\hline I & $4 \cdot 0$ & $2 \cdot 1$ & $5 \cdot 6$ & $5 \cdot 5$ \\
\hline II & $19 \cdot 1$ & $13 \cdot 2$ & $23 \cdot 7$ & $24 \cdot 7$ \\
\hline III Non-manual & 13.5 & 8.8 & 9.6 & $11 \cdot 3$ \\
\hline III Manual & $38 \cdot 4$ & 50.5 & $37 \cdot 7$ & $34 \cdot 4$ \\
\hline IV & $15 \cdot 2$ & $16 \cdot 0$ & $15 \cdot 7$ & $16 \cdot 0$ \\
\hline $\mathrm{V}$ & 6.9 & $7 \cdot 3$ & $6 \cdot 1$ & 6.0 \\
\hline \multirow{5}{*}{$\begin{array}{l}\% \text { Of households with more than one } \\
\text { person per room } \\
\% \text { Of households in dwellings of fewer } \\
\text { than five rooms } \\
\% \text { Of households in owner occupied } \\
\text { dwellings } \\
\% \text { Of households owning a car }\end{array}$} & & & & \\
\hline & $2 \cdot 0$ & $3 \cdot 9$ & $3 \cdot 5$ & $3 \cdot 4$ \\
\hline & $24 \cdot 6$ & $41 \cdot 5$ & $40 \cdot 9$ & $35 \cdot 2$ \\
\hline & $58 \cdot 1$ & $56 \cdot 4$ & $41 \cdot 5$ & $58 \cdot 1$ \\
\hline & $60 \cdot 2$ & $52 \cdot 6$ & $49 \cdot 3$ & 61.5 \\
\hline Total population & 119500 & 249838 & 59622 & \\
\hline
\end{tabular}

${ }^{\star}$ Figures for England and Wales are for male population aged 16 and over. 
TABLE II-Standardised mortality ratios and morbidity among men and women

\begin{tabular}{|c|c|c|c|c|c|c|}
\hline & \multicolumn{2}{|c|}{ Ipswich } & \multicolumn{2}{|c|}{ Stoke } & \multicolumn{2}{|c|}{ Wakefield } \\
\hline & Men & Women & Men & Women & Men & Women \\
\hline \multicolumn{7}{|l|}{$\begin{array}{l}\text { Standardised mortality ratios, } \\
\text { 1968-78 (ages 35-74): }\end{array}$} \\
\hline All causes & 92 & 90 & 120 & 117 & 118 & 131 \\
\hline Ischaemic heart disease & 89 & 79 & 115 & 128 & 117 & 137 \\
\hline Breast cancer & - & 103 & - & 93 & - & 98 \\
\hline $\begin{array}{l}\text { Age standardised yearly incidence } \\
\text { of colonic cancer per } 100000, \\
1979-80 \text { (ages }<75)\end{array}$ & 25 & 18 & 19 & 20 & 12 & 15 \\
\hline $\begin{array}{l}\text { Age standardised percentage } \\
\text { prevalence of gall stones, 1977-8 } \\
(\text { ages } \geqslant 18)\end{array}$ & $14 \cdot 4$ & $29 \cdot 0$ & $13 \cdot 5$ & $17 \cdot 1$ & $6 \cdot 1$ & $13 \cdot 4$ \\
\hline
\end{tabular}

records tended to be higher than those recorded by the local interviewers. The mean daily nutrient intakes in the towns (tables III and IV) were therefore adjusted to take account of the use of diary or recall and the season. Results are shown separately for records completed by JC and the local interviewer.

Among men (table III) intakes of energy, fat, carbohydrate, protein, and total fibre were lowest in Wakefield. Differences in intakes of polyunsaturated and saturated fatty acids were such that in records completed by JC the polyunsaturated to saturated fatty acid ratios were 0.32 in Wakefield, 0.35 in Stoke, and 0.36 in Ipswich, whereas in those completed by local interviewers they were $0 \cdot 29,0 \cdot 31$, and $0 \cdot 36$.

Whereas total carbohydrate intake was highest in Stoke, intake of sugar (defined as naturally occurring and added monosaccharides and disaccharides) was highest in Ipswich. Protein intake was highest in Stoke but the proportions of protein derived from animal sources were similar in

TABLE III-Mean daily intakes of nutrients among men in the three towns. (Results shown separately for records completed by $\mathcal{F C}$ and local interviewer)

\begin{tabular}{|c|c|c|c|c|c|c|c|c|c|c|c|c|c|c|c|c|c|}
\hline & \multirow[b]{2}{*}{$\begin{array}{c}\text { No of } \\
\text { men }\end{array}$} & \multicolumn{2}{|c|}{ Energy $(M \mathrm{~J})$} & \multicolumn{2}{|c|}{ Fat $(g)$} & \multicolumn{2}{|c|}{$\begin{array}{c}\text { Polyunsaturated } \\
\text { fatty acids (g) }\end{array}$} & \multicolumn{2}{|c|}{ Saturated fatty acids (g) } & \multicolumn{2}{|c|}{ Carbohydrate (g) } & \multicolumn{2}{|c|}{ Sugars (g) } & \multicolumn{2}{|c|}{ Protein (g) } & \multicolumn{2}{|c|}{ Total fibre (g) } \\
\hline & & Mean & $\begin{array}{c}95 \% \\
\text { Confidence } \\
\text { interval }\end{array}$ & Mean & $\begin{array}{c}\mathbf{9 5 \%} \\
\text { Confidence } \\
\text { interval }\end{array}$ & Mean & $\begin{array}{c}95 \% \\
\text { Confidence } \\
\text { interval }\end{array}$ & Mean & $\begin{array}{c}95 \% \\
\text { Confidence } \\
\text { interval }\end{array}$ & Mean & $\begin{array}{c}95 \% \\
\text { Confidence } \\
\text { interval }\end{array}$ & Mean & $\begin{array}{c}95 \% \\
\text { Confidence } \\
\text { interval }\end{array}$ & Mean & $\begin{array}{c}95 \% \\
\text { Confidence } \\
\text { interval }\end{array}$ & Mean & $\begin{array}{c}95 \% \\
\text { Confidence } \\
\text { interval }\end{array}$ \\
\hline Ipswich $\left\{\begin{array}{l}\mathrm{JC} \\
\text { Local }\end{array}\right.$ & $\begin{array}{l}119 \\
244\end{array}$ & $\begin{array}{l}10 \cdot 8 \\
10 \cdot 5\end{array}$ & $\begin{array}{l}10.1 \text { to } 11.4 \\
10.0 \text { to } 10.9\end{array}$ & $\begin{array}{l}107 \cdot 9 \\
105 \cdot 0\end{array}$ & $\begin{array}{l}100 \text { to } 116 \\
100 \text { to } 1111\end{array}$ & $\begin{array}{l}14 \cdot 9 \\
14.8\end{array}$ & $\begin{array}{l}13 \text { to } 16 \\
14 \text { to } 16\end{array}$ & $\begin{array}{l}43 \cdot 3 \\
42 \cdot 3\end{array}$ & $\begin{array}{l}40 \text { to } 47 \\
40 \text { to } 45\end{array}$ & $\begin{array}{l}308 \cdot 7 \\
291 \cdot 0\end{array}$ & $\begin{array}{l}289 \text { to } 328 \\
278 \text { to } 304\end{array}$ & $\begin{array}{l}120 \cdot 3 \\
122 \cdot 1\end{array}$ & $\begin{array}{l}110 \text { to } 131 \\
114 \text { to } 130\end{array}$ & $\begin{array}{l}85 \cdot 4 \\
82 \cdot 6\end{array}$ & $\begin{array}{ll}80 \text { to } & 91 \\
79 \text { to } & 86\end{array}$ & $\begin{array}{l}20 \cdot 7 \\
19 \cdot 0\end{array}$ & $\begin{array}{l}19 \text { to } 22 \\
18 \text { to } 20\end{array}$ \\
\hline Stoke $\left\{\begin{array}{l}\text { JC } \\
\text { Local }\end{array}\right.$ & $\begin{array}{l}128 \\
249\end{array}$ & $\begin{array}{l}11 \cdot 6 \\
11 \cdot 4\end{array}$ & $\begin{array}{l}\begin{array}{l}11 \cdot 0 \text { to } 12 \cdot 3 \\
10 \cdot 9 \text { to } 11 \cdot 9\end{array} \\
1.9\end{array}$ & $\begin{array}{l}107 \cdot 9 \\
112 \cdot 0\end{array}$ & $\begin{array}{l}100 \text { to } 116 \\
106 \text { to } 118\end{array}$ & $\begin{array}{l}13 \cdot 7 \\
14 \cdot 5\end{array}$ & $\begin{array}{l}12 \text { to } 15 \\
14 \text { to } 16\end{array}$ & $\begin{array}{l}44 \cdot 2 \\
45 \cdot 1\end{array}$ & $\begin{array}{l}41 \text { to } 48 \\
43 \text { to } 48\end{array}$ & $\begin{array}{l}315 \cdot 1 \\
311 \cdot 4\end{array}$ & $\begin{array}{l}296 \text { to } 334 \\
298 \text { to } 325\end{array}$ & $\begin{array}{l}117.0 \\
110.7\end{array}$ & $\begin{array}{l}107 \text { to } 128 \\
104 \text { to } 118\end{array}$ & $\begin{array}{l}94 \cdot 5 \\
94 \cdot 2\end{array}$ & $\begin{array}{l}89 \text { to } 100 \\
90 \text { to } 98\end{array}$ & $\begin{array}{l}20 \cdot 2 \\
19 \cdot 8\end{array}$ & $\begin{array}{l}19 \text { to } 22 \\
19 \text { to } 21\end{array}$ \\
\hline Wakefield $\left\{\begin{array}{l}\mathrm{JC} \\
\text { Local }\end{array}\right.$ & $\begin{array}{l}110 \\
265\end{array}$ & $\begin{array}{r}10 \cdot 1 \\
9 \cdot 8\end{array}$ & $\begin{array}{l}9.5 \text { to } 10 \cdot 7 \\
9 \cdot 4 \text { 10 } 10.2\end{array}$ & $\begin{array}{l}96 \cdot 5 \\
93 \cdot 2\end{array}$ & $\begin{array}{l}89 \text { to } 104 \\
88 \text { to } 98\end{array}$ & $\begin{array}{l}13 \cdot 2 \\
12 \cdot 5\end{array}$ & $\begin{array}{l}12 \text { to } 15 \\
12 \text { to } 13\end{array}$ & $\begin{array}{l}38 \cdot 6 \\
36 \cdot 8\end{array}$ & $\begin{array}{l}35 \text { to } 42 \\
35 \text { to } 39\end{array}$ & $\begin{array}{l}271 \cdot 2 \\
254 \cdot 1\end{array}$ & $\begin{array}{l}252 \text { to } 291 \\
242 \text { to } 267\end{array}$ & $\begin{array}{l}106 \cdot 0 \\
100.6\end{array}$ & $\begin{array}{l}96 \text { to } 117 \\
94 \text { to } 107\end{array}$ & $\begin{array}{l}84 \cdot 1 \\
82 \cdot 2\end{array}$ & $\begin{array}{l}79 \text { to } 90 \\
79 \text { to } 86\end{array}$ & $\begin{array}{l}17 \cdot 9 \\
17 \cdot 3\end{array}$ & $\begin{array}{l}16 \text { to } 20 \\
16 \text { to } 18\end{array}$ \\
\hline
\end{tabular}

TABLE IV-Mean daily intakes of nutrients among women in the three towns. (Results shown separately for records completed by $\mathcal{F C}$ and local interviewer)

\begin{tabular}{|c|c|c|c|c|c|c|c|c|c|c|c|c|c|c|c|c|c|}
\hline & \multirow[b]{2}{*}{$\begin{array}{l}\text { No of } \\
\text { women }\end{array}$} & \multicolumn{2}{|c|}{ Energy $(M \mathrm{~J})$} & \multicolumn{2}{|c|}{ Fat (g) } & \multicolumn{2}{|c|}{$\begin{array}{c}\text { Polyunsaturated } \\
\text { faty acids }(\mathbf{g})\end{array}$} & \multicolumn{2}{|c|}{ Saturated fatty acids ( $\mathbf{g}$ ) } & \multicolumn{2}{|c|}{ Carbohydrate (g) } & \multicolumn{2}{|c|}{ Sugars (g) } & \multicolumn{2}{|c|}{ Protein $(\mathbf{g})$} & \multicolumn{2}{|c|}{ Total fibre (g) } \\
\hline & & Mean & $\begin{array}{c}95 \% \\
\text { Confidence } \\
\text { interval }\end{array}$ & Mean & $\begin{array}{l}95 \% \\
\text { Confidence } \\
\text { interval' }\end{array}$ & Mean & $\begin{array}{c}95 \% \\
\text { Confidence } \\
\text { interval }\end{array}$ & Mean & $\begin{array}{c}95 \% \\
\text { Confidence } \\
\text { interval }\end{array}$ & Mean & $\begin{array}{c}95 \% \\
\text { Confidence } \\
\text { interval }\end{array}$ & Mean & $\begin{array}{c}95 \% \\
\text { Confidence } \\
\text { interval }\end{array}$ & Mean & $\begin{array}{c}95 \% \\
\text { Confidence } \\
\text { interval }\end{array}$ & Mean & $\begin{array}{c}95 \% \\
\text { Confidence } \\
\text { interval }\end{array}$ \\
\hline Ipswich $\left\{\begin{array}{l}\mathrm{JC} \\
\text { Local }\end{array}\right.$ & $\begin{array}{l}129 \\
263\end{array}$ & $\begin{array}{l}7.1 \\
6.7\end{array}$ & $\begin{array}{l}\begin{array}{l}6.7 \text { to } 7.5 \\
6.4 \text { to } 7.0\end{array}\end{array}$ & $\begin{array}{l}73 \cdot 0 \\
68 \cdot 9\end{array}$ & $\begin{array}{l}67 \text { to } 79 \\
65 \text { to } 73\end{array}$ & $\begin{array}{r}10 \cdot 1 \\
9 \cdot 8\end{array}$ & $\begin{array}{l}9 \text { to } 11 \\
9 \text { to } 11\end{array}$ & $\begin{array}{l}29 \cdot 7 \\
27 \cdot 7\end{array}$ & $\begin{array}{l}27 \text { to } 32 \\
26 \text { to } 29\end{array}$ & $\begin{array}{l}192 \cdot 2 \\
183 \cdot 6\end{array}$ & $\begin{array}{l}179 \text { to } 206 \\
175 \text { to } 192\end{array}$ & $\begin{array}{l}76 \cdot 5 \\
73 \cdot 4\end{array}$ & $\begin{array}{l}69 \text { to } 84 \\
68 \text { to } 79\end{array}$ & $\begin{array}{l}64 \cdot 3 \\
60 \cdot 6\end{array}$ & $\begin{array}{l}61 \text { to } 68 \\
58 \text { to } 63\end{array}$ & $\begin{array}{l}15 \cdot 1 \\
14 \cdot 0\end{array}$ & 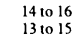 \\
\hline Stoke $\quad\left\{\begin{array}{l}\text { JC } \\
\text { Local }\end{array}\right.$ & $\begin{array}{l}150 \\
266\end{array}$ & $\begin{array}{l}7 \cdot 3 \\
7.2\end{array}$ & $\begin{array}{l}6.9 \text { to } 7.7 \\
6.9 \text { to } 7.5\end{array}$ & $\begin{array}{l}72 \cdot 4 \\
74 \cdot 0\end{array}$ & $\begin{array}{l}671078 \\
701078\end{array}$ & $\begin{array}{l}8.5 \\
9.5\end{array}$ & $\begin{array}{l}8 \text { to } 9 \\
9 \text { to } 10\end{array}$ & $\begin{array}{l}31 \cdot 2 \\
30 \cdot 6\end{array}$ & $\begin{array}{l}29 \text { to } 34 \\
29 \text { to } 32\end{array}$ & $\begin{array}{l}205 \cdot 0 \\
192 \cdot 8\end{array}$ & $\begin{array}{l}192 \text { to } 218 \\
184 \text { to } 202\end{array}$ & $\begin{array}{l}78 \cdot 2 \\
68 \cdot 4\end{array}$ & $\begin{array}{l}71 \text { to } 86 \\
63 \text { to } 74\end{array}$ & $\begin{array}{l}66 \cdot 2 \\
66 \cdot 4\end{array}$ & $\begin{array}{l}63 \text { to } 70 \\
64 \text { to } 69\end{array}$ & $\begin{array}{l}15 \cdot 8 \\
14 \cdot 9\end{array}$ & $\begin{array}{l}\begin{array}{l}15 \text { to } 17 \\
141016\end{array}\end{array}$ \\
\hline Wakefield $\left\{\begin{array}{l}J \mathrm{Cocal} \\
\mathrm{C}\end{array}\right.$ & $\begin{array}{l}120 \\
297\end{array}$ & $\begin{array}{l}7.0 \\
6.4\end{array}$ & $\begin{array}{l}6.5107 .4 \\
6.2106 .7\end{array}$ & $\begin{array}{l}71 \cdot 9 \\
65 \cdot 1\end{array}$ & $\begin{array}{l}661078 \\
61 \text { to } 69\end{array}$ & $\begin{array}{l}8.6 \\
8.7\end{array}$ & $\begin{array}{l}81010 \\
8109\end{array}$ & $\begin{array}{l}30 \cdot 5 \\
26 \cdot 1\end{array}$ & $\begin{array}{l}28+033 \\
24 t 028\end{array}$ & $\begin{array}{l}189 \cdot 4 \\
172 \cdot 4\end{array}$ & $\begin{array}{l}176 \text { to } 203 \\
164 \text { to } 181\end{array}$ & $\begin{array}{l}73 \cdot 0 \\
67 \cdot 2\end{array}$ & $\begin{array}{l}66 \text { to } 81 \\
62 \text { to } 72\end{array}$ & $\begin{array}{l}63 \cdot 1 \\
60 \cdot 8\end{array}$ & $\begin{array}{l}59 \text { to } 67 \\
58 \text { to } 63\end{array}$ & $\begin{array}{l}14 \cdot 0 \\
13 \cdot 4\end{array}$ & $\begin{array}{l}13 \text { to } 15 \\
13 \text { to } 14\end{array}$ \\
\hline
\end{tabular}

TABLE V-Mean daily intakes of fat, carbohydrate, and protein expressed as percentage of energy intake. (Results for records completed by $\mathcal{F C}$ only)

\begin{tabular}{|c|c|c|c|c|c|c|c|}
\hline & \multirow[b]{2}{*}{$\begin{array}{c}\text { No of } \\
\text { subjects }\end{array}$} & \multicolumn{2}{|c|}{ Fat } & \multicolumn{2}{|c|}{ Carbohydrate } & \multicolumn{2}{|c|}{ Protein } \\
\hline & & Mean & $\begin{array}{c}95 \% \\
\text { Confidence } \\
\text { interval }\end{array}$ & Mean & $\begin{array}{c}95 \% \\
\text { Confidence } \\
\text { interval }\end{array}$ & Mean & $\begin{array}{c}95 \% \\
\text { Confidence } \\
\text { interval }\end{array}$ \\
\hline \multicolumn{8}{|c|}{ Men } \\
\hline Ipswich & 119 & $37 \cdot 8$ & 36 to 39 & $48 \cdot 5$ & 47 to 50 & $13 \cdot 5$ & 13 to 14 \\
\hline Stoke & 128 & $34 \cdot 8$ & 33 to 36 & $46 \cdot 5$ & 45 to 48 & $14 \cdot 2$ & 14 to 15 \\
\hline Wakefield & 110 & $36 \cdot 5$ & 35 to 38 & $45 \cdot 4$ & 44 to 47 & $14 \cdot 4$ & 14 to 15 \\
\hline \multicolumn{8}{|c|}{ Women } \\
\hline Ipswich & 129 & $38 \cdot 8$ & 37 to 40 & $46 \cdot 1$ & 45 to 48 & $15 \cdot 8$ & 15 to 17 \\
\hline Stoke & 150 & $37 \cdot 1$ & 36 to 38 & $46 \cdot 3$ & 45 to 48 & $15 \cdot 8$ & 15 to 17 \\
\hline Wakefield & 120 & $39 \cdot 5$ & 38 to 41 & $47 \cdot 1$ & 46 to 48 & $15 \cdot 8$ & 15 to 17 \\
\hline
\end{tabular}

cancer, ${ }^{14}$ and prevalence of gall stones at necropsy ${ }^{2}$ were in the opposite direction to those for ischaemic heart disease, rates in Ipswich being higher than in Wakefield.

Food records were obtained from 2340 subjects ( 1115 men, 1225 women), representing response rates of $86 \%$ in Ipswich, $85 \%$ in Stoke, and $84 \%$ in Wakefield among those who could be contacted. The social class distribution of respondents was closely similar to that of the towns except in Wakefield, where there was overrepresentation of class III non-manual and underrepresentation of class III manual.

Though we sought to standardise the way in which dietary information was obtained, there were differences among the towns. More people in Stoke $(25 \%)$ than in Ipswich (19\%) and Wakefield (20\%) had dietary records based on recall rather than diaries. More of the records in Wakefield (29\%) than in Ipswich (13\%) and Stoke (12\%) were completed in the summer. One of us (JC) interviewed roughly one third of the respondents in Ipswich (33\%), Stoke $(35 \%)$, and Wakefield (29\%). The mean nutrient intakes from her each town-around $60 \%$. About $45 \%$ of the intake of fibre in each town came from cereal products and $16 \%$ from potatoes.

As would be expected, energy intakes were lower in women (table IV) and differences in nutrient intake among the towns were smaller. Similar to men, however, intakes of energy, fat, carbohydrate, sugar, protein, and total fibre were lowest in Wakefield. Carbohydrate and protein intakes were highest in Stoke. The polyunsaturated to saturated fatty acid ratios varied from 0.29 in Wakefield to 0.31 in Stoke and 0.36 in Ipswich for records completed by JC, and from 0.33 to 0.36 and 0.37 respectively for those completed by local interviewers. Higher consumption of vegetables other than potatoes among women in Ipswich resulted in only $37 \%$ of fibre coming from cereal products compared with $45 \%$ in the other towns.

Table $\mathrm{V}$ gives the mean intakes of fat, carbohydrate, and protein as the percentage of total energy derived from them. Only results from interviews conducted by JC are shown. There were no large differences among the towns. 
Social classes were combined to give three groups of similar size-I, II, and III non-manual; III manual; and IV and V. The lower energy intakes in Wakefield were seen in all social class groups. Table VI shows that the lower fat intakes in Wakefield were also not confined to any social class group. Intakes of the nutrients listed in tables III and IV did not show consistent trends with social class. Within each town and in both sexes, however, there was a decrease in intake of vitamin $\mathrm{C}$ from the highest to the lowest social class group.

Body mass index (weight $(\mathrm{kg}) /$ height $(\mathrm{m})^{2}$ ) was highest in Stoke. Among men mean values were 25.6 in Ipswich, 25.8 in Stoke, and 25.6 in Wakefield; among women they were $25 \cdot 1,25 \cdot 4$, and $24 \cdot 6$ respectively. (tables III and IV). Though the social class distribution of these two towns was similar, socioeconomic conditions were worse in Wakefield, both in relation to quality of housing and in relation to income, as indicated by the proportion of households owning their own house or a car. The lower fat consumption in Wakefield was contrary to what might be expected from the high mortality from ischaemic heart disease. It was associated with a lower polyunsaturated to saturated fatty acid ratio and was largely due to lower consumption of milk, cheese, and fats in cakes and puddings. There were only small differences between any of the towns in the

\begin{tabular}{|c|c|c|c|c|c|c|c|c|c|c|}
\hline & & \multicolumn{9}{|c|}{ Social class } \\
\hline & & \multicolumn{3}{|c|}{ I-III Non-manual } & \multicolumn{3}{|c|}{ III Manual } & \multicolumn{3}{|c|}{ IV, V } \\
\hline & & $\begin{array}{c}\text { No of } \\
\text { subjects }\end{array}$ & Mean & $\begin{array}{c}95 \% \\
\text { Confidence } \\
\text { interval }\end{array}$ & $\begin{array}{c}\text { No of } \\
\text { subjects }\end{array}$ & Mean & $\begin{array}{c}95 \% \\
\text { Confidence } \\
\text { interval }\end{array}$ & $\begin{array}{c}\text { No of } \\
\text { subjects }\end{array}$ & Mean & $\begin{array}{c}95 \% \\
\text { Confidence } \\
\text { interval }\end{array}$ \\
\hline Ipswich & $\left\{\begin{array}{l}\mathrm{JC} \\
\text { Local }\end{array}\right.$ & $\begin{array}{l}37 \\
86\end{array}$ & $\begin{array}{l}102 \cdot 7 \\
103 \cdot 1\end{array}$ & $\begin{array}{l}89 \text { to } 117 \\
94 \text { to } 112\end{array}$ & $\begin{array}{l}\text { Men } \\
44 \\
87\end{array}$ & $\begin{array}{l}116 \cdot 9 \\
110 \cdot 2\end{array}$ & $\begin{array}{l}104 \text { to } 131 \\
101 \text { to } 120\end{array}$ & $\begin{array}{l}38 \\
67\end{array}$ & $\begin{array}{l}106 \cdot 2 \\
102 \cdot 1\end{array}$ & $\begin{array}{l}93 \text { to } 121 \\
92 \text { to } 113\end{array}$ \\
\hline Stoke & $\left\{\begin{array}{l}\text { JC } \\
\text { Local }\end{array}\right.$ & $\begin{array}{l}20 \\
56\end{array}$ & $\begin{array}{r}98 \cdot 3 \\
103 \cdot 0\end{array}$ & $\begin{array}{l}81 \text { to } 118 \\
92 \text { to } 115\end{array}$ & $\begin{array}{r}81 \\
128\end{array}$ & $\begin{array}{l}110.9 \\
113.8\end{array}$ & $\begin{array}{l}101 \text { to } 121 \\
106 \text { to } 122\end{array}$ & $\begin{array}{l}26 \\
63\end{array}$ & $\begin{array}{l}107 \cdot 2 \\
118 \cdot 4\end{array}$ & $\begin{array}{r}91 \text { to } 125 \\
107 \text { to } 130\end{array}$ \\
\hline Wakefield & $\left\{\begin{array}{l}\text { JC } \\
\text { Local }\end{array}\right.$ & $\begin{array}{r}55 \\
118\end{array}$ & $\begin{array}{r}105 \cdot 6 \\
93 \cdot 1\end{array}$ & $\begin{array}{l}94 \text { to } 118 \\
86 \text { to } 101\end{array}$ & $\begin{array}{l}28 \\
94\end{array}$ & $\begin{array}{l}79 \cdot 6 \\
93 \cdot 1\end{array}$ & $\begin{array}{l}66 \text { to } 94 \\
85 \text { to } 102\end{array}$ & $\begin{array}{l}26 \\
50\end{array}$ & $\begin{array}{l}87 \cdot 9 \\
91 \cdot 3\end{array}$ & $\begin{array}{l}73 \text { to } 104 \\
80 \text { to } 103\end{array}$ \\
\hline Ipswich & $\left\{\begin{array}{l}\text { JC } \\
\text { Local }\end{array}\right.$ & $\begin{array}{l}55 \\
98\end{array}$ & $\begin{array}{l}70 \cdot 5 \\
75 \cdot 6\end{array}$ & $\begin{array}{l}62 \text { to } 79 \\
69 \text { to } 82\end{array}$ & $\begin{array}{l}\text { Women } \\
41 \\
93\end{array}$ & $\begin{array}{l}75 \cdot 1 \\
63 \cdot 0\end{array}$ & $\begin{array}{l}65 \text { to } 86 \\
57 \text { to } 69\end{array}$ & $\begin{array}{l}28 \\
62\end{array}$ & $\begin{array}{l}78 \cdot 3 \\
67 \cdot 2\end{array}$ & $\begin{array}{l}66 \text { to } 92 \\
60 \text { to } 75\end{array}$ \\
\hline Stoke & $\left\{\begin{array}{l}\mathrm{JC} \\
\text { Local }\end{array}\right.$ & $\begin{array}{l}41 \\
75\end{array}$ & $\begin{array}{l}75 \cdot 8 \\
70 \cdot 9\end{array}$ & $\begin{array}{l}66 \text { to } 87 \\
64 \text { to } 78\end{array}$ & $\begin{array}{r}65 \\
125\end{array}$ & $\begin{array}{l}70 \cdot 3 \\
74 \cdot 8\end{array}$ & $\begin{array}{l}63 \text { to } 78 \\
69 \text { to } 81\end{array}$ & $\begin{array}{l}37 \\
53\end{array}$ & $\begin{array}{l}72 \cdot 3 \\
76 \cdot 6\end{array}$ & $\begin{array}{l}62 \text { to } 83 \\
68 \text { to } 86\end{array}$ \\
\hline Wakefield & $\left\{\begin{array}{l}\mathrm{JC} \\
\text { Local }\end{array}\right.$ & $\begin{array}{r}52 \\
130\end{array}$ & $\begin{array}{l}71 \cdot 5 \\
66 \cdot 1\end{array}$ & $\begin{array}{l}63 \text { to } 81 \\
61 \text { to } 72\end{array}$ & $\begin{array}{l}31 \\
80\end{array}$ & $\begin{array}{l}74 \cdot 5 \\
67 \cdot 3\end{array}$ & $\begin{array}{l}63 \text { to } 87 \\
61 \text { to } 74\end{array}$ & $\begin{array}{l}33 \\
77\end{array}$ & $\begin{array}{l}70 \cdot 1 \\
59 \cdot 7\end{array}$ & $\begin{array}{l}60 \text { to } 82 \\
53 \text { to } 66\end{array}$ \\
\hline
\end{tabular}

TABLE VII-Percentage distribution of men and women in each town stratified by alcohol intake and cigarette smoking

\begin{tabular}{|c|c|c|c|c|c|c|c|c|}
\hline & \multicolumn{4}{|c|}{ Alcohol intake ${ }^{\star}$} & \multicolumn{4}{|c|}{ Cigarette smoking $\dagger$} \\
\hline & $\begin{array}{c}\text { No of } \\
\text { subjects }\end{array}$ & None & Light & $\begin{array}{c}\text { Moderate/ } \\
\text { heavy }\end{array}$ & $\begin{array}{c}\text { No of } \\
\text { subjects }\end{array}$ & Non-smoker & Ex-smoker & $\begin{array}{l}\text { Current } \\
\text { smoker }\end{array}$ \\
\hline & & & & Men & & & & \\
\hline Ipswich & 364 & 8 & 49 & 43 & 363 & 29 & 25 & 40 \\
\hline Stoke & 378 & 6 & 27 & 67 & 378 & 23 & 26 & 43 \\
\hline \multirow[t]{2}{*}{ Wakefield } & 375 & 5 & 35 & 60 & 373 & 28 & 25 & 36 \\
\hline & & & & Women & & & & \\
\hline Ipswich & 392 & 17 & 72 & 11 & 388 & 52 & 16 & 32 \\
\hline Stoke & 417 & 14 & 61 & 25 & 415 & 47 & 18 & 35 \\
\hline Wakefield & 419 & 11 & 68 & 21 & 416 & 43 & 18 & 39 \\
\hline
\end{tabular}

$\star$ See text for definition of levels.

†Six per cent of men in Ipswich, $8 \%$ in Stoke, and $11 \%$ in Wakefield were either past or current smokers of other tobacco products.

Table VII shows that Ipswich had the lowest proportion of heavy drinkers, defined as people having six or more drinks on one or two days a month or three or more drinks at weekends or on most days of the week. Among men the proportion of current cigarette smokers was highest in Stoke (43\%); among women the proportion was highest in Wakefield (39\%).

\section{Discussion}

This is the first large scale survey of nutrient intakes of people of middle age living in different areas of Britain. The samples were selected to be representative of the population of each town in the age range 35-54 years and were large enough to detect differences among the towns likely to be of biological importance. The response rate was $85 \%$.

By comparison with international differences in dietary intakes the differences found among the towns in this study were small. This is in keeping with the small dietary differences among the regions of Britain estimated by the National Food Survey from household food purchases. ${ }^{1}$

The mean daily intakes of energy, fat, and all main nutrients were lower in the northern industrial town (Wakefield) than in the southern market town (Ipswich) among both men and women amounts of fat derived from meat, fried potatoes, butter, or margarine. When expressed as a proportion of total energy the consumption of fat in the three towns was similar (table V). There was not a consistent trend in fat consumption by social class within the towns (table VI). The survey was able to show social class differences in vitamin $\mathrm{C}$ intake similar to those reported by the National Food Survey.

The lower mean intakes of total fibre in Wakefield reflected lower consumption of vegetables other than potatoes. Consumption of cereal fibre, however, was lowest in Ipswich, with a mean of $7.4 \mathrm{~g}$ per person daily compared with $7.5 \mathrm{~g}$ in Wakefield and $8.4 \mathrm{~g}$ in Stoke. These findings are in keeping with the general trend of lower consumption of non-potato vegetables and higher consumption of cereals in less affluent communities within the British Isles. ${ }^{15}$

The mean daily intakes of energy and carbohydrate were highest in Stoke (tables III and IV). This town has the highest proportion of manual workers (table I). The higher intakes were seen, however, in all social classes and in both men and women. Mean body mass index was also highest in Stoke.

Our findings suggest that the geographical inequalities in mortality in Britain, in particular mortality from ischaemic heart disease, cannot be attributed to differences in consumption of energy or fat during middle life. There is evidence that cigarette smoking may 
contribute to the inequalities among men, as the regional heart study of 24 towns showed a correlation between smoking and the prevalence of ischaemic heart disease. ${ }^{16}$ Information about women is lacking, except that throughout England and Wales mortality from ischaemic heart disease correlates negatively with mortality from lung cancer, an indicator of cigarette smoking. ${ }^{17}$ In the three towns in our study the small differences in cigarette smoking among men did not correspond with the differences in ischaemic heart disease, but the highest proportion of smokers among women was in Wakefield. The regional heart study has not found alcohol consumption to be an important determinant of variations in cardiovascular mortality. ${ }^{9}$ In the three towns the proportion of heavy drinkers was, however, lowest in Ipswich.

Socioeconomic conditions are better in Ipswich than in the other two towns (table I). It might be expected that a more affluent town would tend to have higher rather than lower intakes of fat and other components of a Western diet. It is also consistent that it had higher rates of breast cancer, colonic cancer, and gall stones (table II), all of which are more common in affluent countries. The low mortality from ischaemic heart disease is paradoxical. The results of this study are in keeping with recent findings which suggest that the explanation may lie more in the better development and health of children in Ipswich in the past than in a more healthy diet among adults at present. ${ }^{1718}$

We are grateful to the subjects in the three towns who took part in this study, to their general practitioners, and to the local interviewers Jane Whitehead, Lesley Raper, and Sylvia Kirkham. We also thank our colleagues in the MRC Environmental Epidemiology Unit, in particular Dr Michael Nelson, who advised on dietary methods, and Mr Paul Winter, who helped with computing.

\section{References}

1 Ministry of Agriculture, Fisheries and Food. Household food consumption and expenditure survey, 1985. London: HMSO, 1987.

2 Barker DJP, Gardner MJ, Power C, Hutt MSR. Prevalence of gall stones at necropsy in nine British towns: a collaborative study. Br Med f 1979;ii: 1389-92.

3 Office of Population Censuses and Surveys. Small area statistics. Census 1981. London: HMSO, 1982.

4 Office of Population Censuses and Surveys. Area mortality decennial supplement 1969-73, England and Wales. London: HMSO, 1981. (Series DS, No 4.)

5 Cole T, Black A. Statistical aspects in the design of dietary surveys. In: Dietary assessment of populations. Southampton: Medical Research Council Environmental Epidemiology Unit, 1984. (Scientific report No 4.)

6 Bingham S, McNeil NI, Cummings JH. The diet of individuals: a study of a randomly-chosen cross section of British adults in a Cambridgeshire village. Br f Nutr 1981;45:23-35.

7 Thomson M, Logan RL, Sharman M, Lockerbie L, Riemersma RA, Oliver MF. Dietary survey in 40-year old Edinburgh men. Hum Nutr Appl Nutr 1982;36A:272-80.

8 Yarnell JWG, Fehily AM, Milbank JE, Sweetnam PM, Walker CL. A short dietary questionnaire for use in an epidemiological survey: comparison with weighed dietary records. Hum Nutr Appl Nutr 1983;37A:103-12.

9 Shaper AG, Phillips AN, Pocock SJ, Walker M. Alcohol and ischaemic heart disease in middleaged British men. BrMed F 1987;294:733-7.

10 Paul AA, Southgate DAT. McCance and Widdowson's the composition of foods. 4th ed. London: HMSO, 1978.

11 Paul AA, Southgate DAT, Russel J. First supplement to McCance and Widdowson's the composition of foods. London: HMSO, 1980.

12 Wiles SJ, Nettleton PA, Black AE, Paul AA. The nutrient composition of some cooked dishes eaten in Britain: a supplementary food composition table. Fournal of Human Nutrition 1980;34:189-223.

13 Baker RJ, Nelder JA. GLIM (generalised linear interactive modelling), release 3. Oxford: Numerical Algorithms Group, 1978.

14 Barker DJP, Godfrey KM. Geographical variations in the incidence of colorectal cancer in Britain Brf Cancer 1984;50:693-8.

15 Morris J, Barker DJP, Nelson M. Diet, infection and acute appendicitis in Britain and Ireland. f Epidemiol Community Health 1987;41:44-9.

16 Shaper AG. Geographic variations in cardiovascular mortality in Great Britain. Br Med Bull 1984;40:366-73.

7 Barker DJP, Osmond C. Infant mortality, childhood nutrition and ischaemic heart disease in England and Wales. Lancet 1986;i:1077-81.

18 Barker DJP, Osmond C. Inequalities in health in Britain: specific explanations in three Lancashire towns. Br Med F 1987;294:749-52.

(Accepted 18 fanuary 1988)

\section{SHORT REPORTS}

\section{High dose intravenous gammaglobulin in chronic systemic juvenile arthritis}

The effect of high dose intravenous gammaglobulin has been described in several immunological disorders including idiopathic thrombocytopenic purpura, ${ }^{1}$ autoimmune neutropenia, ${ }^{2}$ and myasthenia gravis. ${ }^{3}$ We report a case of severe chronic systemic juvenile arthritis with a remarkable response to high dose intravenous gammaglobulin.

\section{Case report}

A 6 year old boy was admitted in October 1983 with a history of polyarthritis rash, and high spiking fever. These symptoms persisted, and he developed pleurisy and myocarditis. He was treated with prednisolone for three years, this being the only drug that reduced the symptoms. Salicylates, though slightly effective, caused intolerable tinnitus and hearing loss; no response was observed to other non-steroidal anti-inflammatory drugs. Hydroxychloroquine sulphate caused retinopathy, penicillamine induced a severe allergic reaction, and cytotoxic drugs (azathioprine, methotrexate, and cyclophosphamide) had no beneficial effect.

Unfortunately, prednisolone caused severe osteoporosis, which resulted in three fractured vertebrae. In December 1986 treatment was changed to high dose intravenous gammaglobulin. A daily dose of $400 \mathrm{mg} / \mathrm{kg}$ body weight was given for five days, followed by a single dose of $800 \mathrm{mg} / \mathrm{kg}$ once every fortnight. The fever, rash, and arthritis resolved within 24 hours and did not recur for two weeks. Morning stiffness was considerably reduced, and the patient felt well. Subsequently short episodes of fever and inflammation of three joints recurred at the end of January 1987. A high dose regimen of $400 \mathrm{mg} / \mathrm{kg}$ daily for five days every three weeks was started. Six courses were given, and during this time the patient developed fever, rash, and polyarthritis for several days on three occasions. These symptoms resolved after the first day of the next course.

The polyarthritis and systemic symptoms recurred in October, four months after gammaglobulin was stopped. Treatment was restarted in November with $400 \mathrm{mg} / \mathrm{kg}$ daily for five days followed by courses of $1000 \mathrm{mg} / \mathrm{kg}$ over two days every three weeks. The systemic symptoms and arthritis were again reduced, but only after two and a half weeks. This regimen was continued, and during December 1987 the fever, rash, and arthritis did not recur.

During the three weeks after high dose intravenous gammaglobulin was first
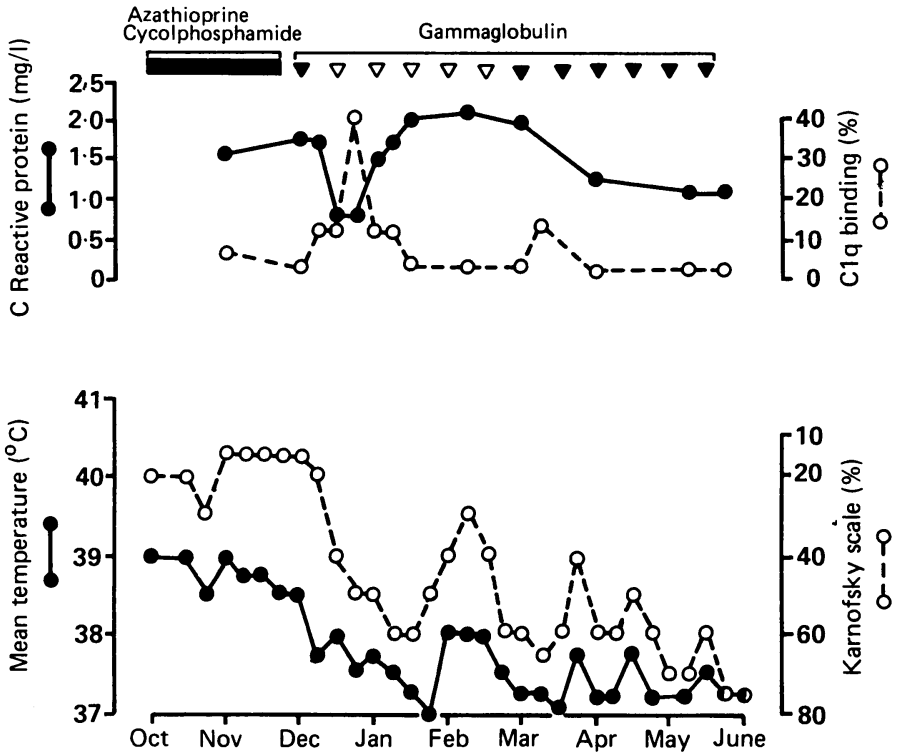

Clinical course of disease as indicated by $\mathrm{C}$ reactive protein and $\mathrm{Clq}$ binding concentrations, mean body temperature, and quality of life according to Karnofsky scale $(10 \%=$ very ill and wholly dependent on outside help, $80 \%=$ only few interferences with activities of daily living) during treatment with gammaglobulin from October 1986 to June $1987 . \nabla=60 \mathrm{~g}$ in five days; $\nabla=24 \mathrm{~g}$ in one day.

given the haemoglobin concentration rose from $85 \mathrm{~g} / \mathrm{l}$ to $103 \mathrm{~g} / \mathrm{l}$, and total serum IgG concentration from $21.0 \mathrm{~g} / \mathrm{l}$ to $32 \cdot 6 \mathrm{~g} / \mathrm{l}$.

The figure summarises the clinical course, showing the considerable rise in $\mathrm{Clq}$ binding (representing circulating immune complexes) and the fall in $\mathrm{C}$ reactive protein concentration. IgM rheumatoid factor rose from 12.5 to 200 immunising units/ml. 